\title{
EDUCACIÓN AMBIENTAL: PERCEPCIONES DE LOS AGENTES QUE TRABAJARON EN EL PROYECTO PARA REVITALIZAR UN PARQUE URBANO EN EL MUNICIPIO DE CONFRESA/MT
}

\author{
Katiany dos Santos Pereira \\ KatianydosSantos@outlook.com \\ https://orcid.org/0000-0002-3121-9692 \\ Marcelo Franco Leão \\ marcelo.leao@cfs.ifmt.edu.br \\ http://orcid.org/0000-0002-9184-916X \\ Instituto Federal de Educação, Ciência e Tecnologia de Mato Grosso - IFMG \\ Brasil
}

Recibido: 2020-04-22; Aceptado: 2020-11-12

\section{Resumen}

Desarrollar acciones dirigidas a la conservación del medio ambiente, con el fin de provocar la reflexión sobre cuestiones ambientales, es una forma de Educación Ambiental (EA). El objetivo de este estudio es describir cómo los agentes que trabajaron en el proyecto de revitalización de Eco Park perciben las acciones desarrolladas como un medio para promover la EE. La revitalización propuesta para este parque en el municipio de Confresa / MT, tuvo lugar en 2019, a través de tres acciones para mejorar la calidad del lugar y crear conciencia entre la población que lo frecuenta. Con base en las acciones realizadas, se aplicó un cuestionario con 10 preguntas a 12 agentes responsables de la elaboración y desarrollo del proyecto. Para analizar los datos, se adoptó la técnica de Análisis de Contenido. Se identificaron 5 categorías: problemas ambientales en la región; Educación ambiental y revitalización de Eco Park; Participación en el proyecto y cambios a través de las acciones desarrolladas; Aprendizaje, beneficios y mejoras para el parque; Desarrollo sostenible y sensibilización. Por lo tanto, se observó que los agentes entienden el concepto y la percepción de EA, exponiendo la importancia del proyecto, citando problemas ambientales presentes en el entorno en el que se insertan y acciones que aún deben llevarse a cabo en el parque, en el municipio y especialmente en las escuelas de la región. Palabras clave: Educación ambiental, medio ambiente, revitalización.

\section{ENVIRONMENTAL EDUCATION: PERCEPTIONS OF AGENTS WHO WORKED ON THE PROJECT TO REVITALIZE AN URBAN PARK IN THE MUNICIPALITY OF CONFRESA/MT}

\begin{abstract}
Developing actions aimed at environmental conservation, in order to provoke reflection on environmental issues, is a form of Environmental Education (EE). The aim of this study is to describe how the agents who worked on the Eco Park revitalization project perceive the actions developed as a means of promoting EE. The proposed revitalization for this park in the municipality of Confresa / MT, took place in 2019, through three actions to improve the quality of the place and raise awareness among the population that frequents it. Based on the actions
\end{abstract}


carried out, a questionnaire with 10 questions was applied to 12 agents responsible for the elaboration and development of the project. To analyze the data, the Content Analysis technique was adopted. There were 5 categories identified: Environmental problems in the region; Environmental education and the revitalization of Eco Park; Participation in the project and changes through the actions developed; Learning, benefits and improvement for the park; Sustainable development and awareness. Therefore, it was noticed that the agents understand the concept and perception of AE, exposing the importance of the project, citing environmental problems present in the environment in which they are inserted and actions that still need to be carried out in the park, in the municipality and especially in the schools of the region.

Keywords: Environmental education, environment, evitalization.

\section{EDUCAÇÃO AMBIENTAL: PERCEPÇÕES DOS AGENTES QUE ATUARAM NO PROJETO DE REVITALIZAÇÃO DE UM PARQUE URBANO NO MUNICÍPIO DE CONFRESA/MT}

\section{Resumo}

Desenvolver ações voltadas à conservação do meio ambiente, de maneira a provocar reflexão sobre as problemáticas ambientais, é uma forma de Educação Ambiental (EA). O objetivo deste estudo é descrever como os agentes que atuaram no projeto de revitalização do Eco Park percebem as ações desenvolvidas como meio de promover EA. A revitalização proposta para este parque do município de Confresa/MT, ocorreu em 2019, por meio de três ações para melhorar a qualidade do local e sensibilizar da população que o frequenta. A partir das ações executadas, aplicou-se um questionário com 10 perguntas para 12 agentes responsáveis pela elaboração e desenvolvimento do projeto. Para analisar os dados, adotou-se a técnica da Análise de Conteúdo. Foram 5 as categorias identificadas: Problemas ambientais da região; A educação ambiental e a revitalização do Eco Park; A participação no projeto e as mudanças por meio das ações desenvolvidas; Aprendizagem, benefícios e melhoria para o parque; Desenvolvimento sustentável e sensibilização. Logo, notou-se que os agentes compreendem o conceito e a percepção da EA, expondo a importância do projeto, citando problemas ambientais presentes no ambiente em que estão inseridos e ações que ainda precisam ser realizadas no parque, no município e principalmente nas escolas da região.

Palavras-chave: Educação Ambiental, meio ambiente, revitalização.

Introdução

Os processos de organização das sociedades atuais por volta do século XVIII e século XIX foram conduzidos pela grande expansão da Revolução Industrial. As cidades foram ganhando novas formas com o avanço populacional e consequentemente houve um crescimento exagerado da exploração da natureza para consumo (Lima \& Rocha, 2009).

Gonçalves, Lima e Marques (2019) afirmam que a exploração da natureza exageradamente tem a possibilidade de colocar a sobrevivência em risco no planeta Terra. Se por um lado temos o desenvolvimento econômico, do outro lado tem as consequências de tal 
avanço, como: degradação dos recursos naturais, perda da biodiversidade, redução da qualidade e quantidade da água potável, diminuição da camada de ozônio e acúmulo de gases responsáveis pelo efeito estufa na atmosfera.

Diante de várias ameaças que o meio ambiente está enfrentando é importante criar medidas de recuperação a biodiversidade em conjunto a Educação Ambiental (EA). Tais medidas devem focar na sensibilização e conscientização ambiental como, por exemplo, na revitalização de áreas verdes urbanas, devido ao grande índice de poluição gerada.

Os parques urbanos têm a finalidade de proporcionar um contato maior com a natureza, pois, a maioria da população que vive em cidades tem pouco acesso à interação com o meio ambiente. Diante do enunciado, faz-se necessário uma abordagem da EA que leve as pessoas a se conscientizarem para a utilização racional dos recursos naturais e assim ocorrer o desenvolvimento sustentável (Franco et al., 2012).

No que lhe concerne, a revitalização urbana consiste na recuperação de áreas que são utilizadas de formas incorretas ou por abandono, ocorrendo à degradação. Esse processo tem como principal objetivo mudanças de restruturações e reconstruções por meio de um planejamento do município.

Ser servidora da Secretaria de Planejamento da Prefeitura Municipal de Confresa/MT e ainda cursar Biologia no IFMT Campus Confresa, foram os pontos principais para a elaboração do projeto. Assim, a iniciativa pelo projeto de revitalização surgiu pela necessidade de criar ações e práticas educativas ligadas a EA para preservação e conservação do meio ambiente, com o intuito de alertar a população sobre os impactos ambientais e maneiras viáveis de uma consciência cidadã.

O presente estudo consiste em descrever como os agentes que atuaram no projeto de revitalização do Eco Park percebem as ações desenvolvidas como meio de promover EA. Esse parque fica localizado em uma área urbana de Confresa-MT de $56.058 \mathrm{~m}^{2}$, no residencial Imperial Eco Park, que é dividido em duas áreas pela Av. José Bernardes Pinto.

Para a elaboração e execução do projeto de revitalização contou com o apoio Secretaria de Planejamento, Secretaria de Agricultura e Meio Ambiente, Secretaria de Educação, Secretaria de Obras e Cultura, bem como Policia Militar, Sindicato Rural, Conselho Tutelar, Escolas, ONGS, além dos moradores da localidade. 
Antes das ações desenvolvidas, o parque se encontrava em situação degradada pela população local, devido à falta de sensibilização ambiental. Lixo jogado no chão e dentro da represa, poluição sonora com carros de som automotivo e consumo de drogas lícitas e ilícitas eram uns dos problemas encontrados no local.

A partir desses problemas encontrados, o estudo visa responder a seguinte pergunta: Como os agentes que atuaram na revitalização do Eco Park percebem a EA envolvida no projeto? Esse projeto de intervenção teve como objetivo melhorar as condições de infraestrutura e limpeza do local. Para isso, foi necessário realizar um levantamento para identificar a situação do ambiente e buscar parceiros para abrangência da sensibilização ambiental, tendo como o princípio à preservação para futuras gerações.

\section{Princípios da Educação Ambiental}

A Conferência de Organização das Nações Unidas (1972) em Estocolmo sobre o ambiente humano é um ponto de partida internacional para as emergências das políticas ambientais. O plano da Conferência de Estocolmo teve como principal objetivo educar o cidadão em respeito aos problemas ambientais, surgindo assim o que conhecemos hoje como EA (Oliveira, 2018).

De acordo com Carneiro et al. (2016) e Fonseca (2016), as questões ambientais estão se tornando progressivamente assunto de extrema urgência em relação à preservação, conservação e conscientização do meio ambiente. Deste modo a EA é um processo mundial, que visa criar formas e maneiras conscientes de preservação e conservação para desempenhar melhorias e proteger o meio ambiente.

A educação ambiental vem sendo construída com diversos conceitos e abordagens, mas que coincidem na intenção em construir outro ser humano, que possa estar mais integrado à natureza e em si mesmo, diferindo em si no caminho e na forma de se construir um processo educacional. O conceito de educação ambiental vem se aprimorando ao longo do tempo, assim como outros conceitos que tratam da relação do homem com o meio ambiente, tal como o desenvolvimento sustentável, e se adaptando à realidade social que o homem se encontra (Silva, 2017, p. 7).

Entende-se por preservação, o cuidado com a natureza sem a modificação/utilização dos recursos naturais sem nenhuma intervenção humana e a conservação defende uma maneira de desenvolvimento sustentável dos recursos, garantido melhor qualidade de vida. 
A EA se estende do contato com o meio ambiente até aos espaços formais da educação. A escola nesse contexto possui a finalidade de promover uma educação integral dos estudantes inserindo na dimensão ambiental, mas também na formação do caráter, do senso de solidariedade e de justiça, percebendo assim o mundo de uma forma crítica (Hofstatter et al., 2016; Rodrigues \& Sahab, 2018).

No âmbito escolar a EA não apresenta como uma nova disciplina, ela deve ser trabalhada interdisciplinarmente na busca do conhecimento integrado. Leite et al. (2017) elucidam que a EA deve estar presente nas relações e atividades escolares para pôr em prática um pensamento ecologista mundial, assim o papel da escola é de formar estudantes com a sensibilização a respeito das ações ambientais.

Deste modo, os professores e formadores de opiniões precisam lançar metas e ações para a mitigação de quaisquer crises e problemas ambientais, levando a integração da escola, comunidade e meio ambiente à construção de uma sociedade capaz de enxergar as gravidades e os impactos de seus atos (Figueiredo, 2017).

No trabalho desenvolvido por Guimarães (2016), a EA é uma das dimensões do processo educacional, podendo ter diferentes projetos educacionais com distintos olhares sociais do mundo, alcançando assim uma EA conservadora e uma EA crítica. A conservadora compreende as práticas informativas e comportamentais, enquanto a crítica aponta a dominação do Ser Humano e suas ações para as transformações da sociedade em relação ao equilibro socioambiental.

A EA pode-se apresentar também de forma Informativa, Vivencial e Construtivista. A Informativa (Educação sobre ambiente) tem enfoque na aquisição de conhecimento em que o meio ambiente se torna um objeto de aprendizado. A Vivencial (educação no meio ambiente) proporciona contato com a natureza, assim o meio ambiente se torna um meio de aprendizado. A Construtivista (educação para o ambiente) busca por meio de projetos e ações de intervenções a prevenção de problemas ambientais (Sorrentino \& Trabjer, 2007).

Cruz et al. (2016) ressaltam que o papel da EA não é impor modelos comportamentais para a sociedade, é preciso que cada cidadão construa hábitos e atitudes voltadas a preservação e conservação do meio ambiente.

No Brasil, a EA passou a integrar as ações do governo desde 1973, com a criação da primeira Secretaria Especial do Meio Ambiente (SEMA), e nas décadas de 80 a 90 à EA se 
tornou mais conhecida devido ao avanço da sensibilização ambiental, devido aos grandes problemas ambientais enfrentados na contemporaneidade (Carvalho, 2004).

A Lei no 9.795/99 dispõe sobre a EA, sendo uma educação voltada para a construção coletiva de valores sociais e conhecimentos presentes na educação nacional de forma em todos os níveis e modalidades de ensino, devendo estar presente de forma articulada, em caráter formal e não formal (Lima \& Sobrinho, 2017). Os autores ainda abordam que a lei define a EA como uma construção de habilidades, atitudes e competências voltadas para a conservação do ambiente, enunciando princípios básicos e apontando os objetivos fundamentais da EA.

$\mathrm{O}$ artigo $4^{\circ}$ da lei $9.795 / 99$, afirma os princípios básicos:

Art.4 $4^{\circ}$ São princípios básicos da educação ambiental:

I - o enfoque humanista, holístico, democrático e participativo;

II - a concepção do meio ambiente em sua totalidade, considerando a interdependência entre o meio natural, o socioeconômico e o cultural, sob o enfoque da sustentabilidade.

Assim, todos que estão inseridos em um meio social devem ter a preocupação com as suas ações geradas e sobre os impactos que as mesmas têm ao meio ambiente, levando a participação dos envolvidos para a resolução dos desafios que é exposto a respeito da mitigação dos problemas ambientais.

\section{Problemas Ambientais Atuais}

A grande preocupação neste século sobre problemas ambientais tem tornado uma grande questão para o nosso planeta a respeito da crise ambiental, ganhando repercussão nos meios de comunicação e no cotidiano da sociedade. Destacam-se também os movimentos ambientalistas, institutos de pesquisas e encontros internacionais, que se mobilizam a desenvolver práticas que reduzam os impactos causados e a degradação ambiental (Junior \& Sá, 2017; Sulaiman \& Aledo, 2016).

No estudo desenvolvido por Santos e Gardolinski (2016), é exposto que os problemas ambientais se introduziram em pauta entre 1960 a 1970. Os autores abordam que as grandes constatações científicas sobre os danos que estavam sendo causados ao planeta devido à exploração dos recursos naturais, consumo desenfreado produzido pela industrialização e a falta de cuidado com o destino de resíduos sólidos, foram circunstâncias chaves para se pensar nos impactos do desequilíbrio ambiental. 
“A intensificação do processo de urbanização é um dos grandes indutores dos atuais problemas ambientais devido à diversificação de usos da terra, à degradação dos solos, à retirada da vegetação, etc.” (Stanganini \& Lollo, 2018, p. 119).

De acordo com Pitanga (2016), a crise ambiental é um processo que vai além dos limites físicos dos recursos naturais. Ela também é discutida com uma crise do conhecimento, evidenciando os primeiros problemas nos atores principais dessa história e a educação como um instrumento necessário para seu enfrentamento. "As discussões centradas na chamada "crise ambiental" compõem diversos debates científicos, políticos, econômicos e sociais voltados para a questão ambiental" (Reis \& Silva, 2016, p. 146).

Carvalho et al. (2016) e Budzilo (2016) apresentam ainda que uns dos principais problemas ambientais que a sociedade está enfrentando é o aumento na produção do lixo. $\mathrm{O}$ consumo exagerado da sociedade leva a uma grande desordem na produção e também no ambiente, repercutindo na falta de conscientização pessoal para o hábito de utilizar o local correto para o destino do lixo, que causam bastantes problemas para os indivíduos.

A degradação das áreas verdes em função do crescimento populacional é também um grave problema enfrentado pelas cidades, pois, essas áreas agem como proteção contra o assoreamento dos cursos d'agua, do solo quanto à erosão e regularização dos regimes hídricos (Rubira, 2016).

Outra questão envolvida neste contexto são os espaços livres como as áreas verdes dentro da cidade, caracterizados como parques ou jardins possuindo cunho recreativo e comunitário, mas como estão inseridos em locais com índice populacional sofrem de ações de constante degradação ambiental por falta de conscientização e sensibilização ecológica (Rubira, 2016; Silva, 2016).

No estudo desenvolvido por Barbosa et al. (2017), os autores destacam que para que ocorra uma mudança significativa no comportamento e conscientização a respeito dos problemas ambientais é preciso ter uma união entre os seres humanos e o meio ambiente que eles se encontram inserido. A partir dessa ligação, os autores ainda abordam um processo de interação, e preocupação com o meio ambiente por meio da percepção ambiental.

A percepção ambiental é um elemento voltado para a educação EA, relacionando a natureza e atribuição de valores e conhecimento entre grupos de indivíduos de diferentes culturas para promover uma sensibilização ambiental (Ostrovski \& Ostrovski, 2015). 


\section{Revitalização de Áreas Urbanas}

Com o passar do tempo, as edificações e estruturas das cidades chamam a atenção pela necessidade de um processo de transformação devido à degradação. Assim surgem as oportunidades de valorização e de ser trabalhar uma educação ambiental capaz de conscientizar e sensibilizar possíveis locais culturais e sociais por meio da revitalização desses espaços (Gaspar et al., 2017). Segundo Teixeira (2016), as áreas verdes urbanas surgiram desde o Egito Antigo considerado como jardins. Com o processo de Revolução Industrial foram surgindo áreas verdes maiores conhecidas também como parques urbanos ganhando cada vez mais espaços nas cidades.

A revitalização de áreas urbanas é um tema de diversos estudos, compreendendo a ações e estratégias de recuperação de locais abandonados e degradados que teve início por volta da década de 60 , com o movimento progressista italiano, que tinha como objetivo a restauração e preservação de edifícios e centros históricos (Jardim, 2012). A revitalização trata-se de recuperar o espaço ou construção (Tanscheit, 2017). A autora aborda que uma área revitalizada beneficia toda a população e não somente um grupo específico.

Zancheti et al. (2015) apontam alguns projetos de revitalização no Brasil como, por exemplo:

Em Salvador, em 1992 inicia o processo de revitalização que teve como características a reforma urbanística e de imóveis com a mudança radical de usos, introdução de habitação e novo mix comercial. Os objetivos eram mudar radicalmente o perfil de público e atividades para a criação de uma área de comércio, lazer, cultura, turismo e habitação, usando como estratégia a aplicação de investimentos públicos do governo estadual e municipal no apoio a promoção de atividades culturais e subsídios para empresas privadas na área de lazer, alimentação e comércios (Zancheti et al., 2015, p. 7).

Gaspar et al. (2017), ainda mostram ações de revitalização elaboradas pelo projeto Centro Sapies, que tem como principal objetivo transformar o Centro Histórico da cidade de Florianópolis, incentivando assim uma conexão entres os cidadãos e a cidade em desenvolvimento.

Outros exemplos de revitalização trazidos no trabalho de Zancheti et al. (2015), foram a: recuperação urbana e produzir espaços adaptados para atividades de comércios, serviços e cultura que atraíssem a população em São Luiz/MA, em São Paulo/SP o projeto de revitalização 
teve como característica a inclusão de equipamentos culturais e de lazer como atração de novos usuários, a transformação do mix de atividades econômicas e pôr fim a tentativa da mudança na paisagem urbana e em Rio de Janeiro o Projeto Corredor Cultural com objetivo de ir além da preservação de edifícios isolados, introduzindo a questão da preservação das ambiências e de estruturas físicas em conjuntos.

\section{Procedimentos Metodológicos}

A metodologia adotada nesse estudo foi elaborada em três etapas: revisão bibliográfica, revitalização do parque urbano Eco Park e aplicação de questionários sobre a percepção da EA no projeto de revitalização.

A primeira etapa do estudo foi realizada no período de setembro a novembro de 2019 por meio da realização de uma revisão bibliográfica sobre os temas: educação ambiental, problemas ambientais e revitalização de áreas urbanas. Utilizaram-se como bases de dados: anais de eventos, sites, livros, publicações em revistas científicas e teses de graduação, especialização e mestrado disponíveis na Scielo Brasil, Portal de Periódicos Capes e nos acervos da biblioteca do Instituto Federal de Mato Grosso, Campus Confresa, delimitando-se para publicações em revistas um período de quatro anos, de 2015 a 2018 e teses um período de dez anos, de 2009 a 2018.

Segundo Marconi e Lakatos (2007), a pesquisa bibliográfica abrange a toda bibliografia desde publicações avulsas, boletins, jornais, revistas, livros, pesquisas, monografias, teses, etc., acessível ao público que realiza estudo do tema e tem a finalidade de colocar o pesquisador em contato com tudo que já foi escrito, dito ou filmado.

A segunda etapa consistiu na revitalização do parque urbano Eco Park, no período de setembro a novembro de 2019. Essa área urbana está situada a 10³9’26.7' ' S, 51³5’09.0' $\mathrm{W}$, na entrada do Loteamento Imperial Eco Park, no município de Confresa-MT. As ações de revitalização foram realizadas em parceria com a Secretaria Municipal de Planejamento, Secretaria de Agricultura e Meio Ambiente, Secretaria de Educação, Secretaria de Obras e Secretaria de Cultura, Policia Militar, Sindicato Rural, Conselho Tutelar, Escolas, ONGs (Engajamundo e Associação dos Agentes Ambientais Voluntários), além dos moradores da localidade em que a ação foi desenvolvida. 
O projeto de revitalização urbana foi elaborado como uma intervenção a médio e longo prazo, sobre uma perspectiva de sustentabilidade ambiental em áreas verdes, promovendo vantagens para o meio ambiente e as comunidades envolvidas para uma melhor qualidade de vida em colaboração com órgãos públicos (Moura et al., 2006).

A etapa de revitalização dividiu em 3 (três) ações, (1) Identificar os principais problemas do parque; (2) Limpeza do local e poda das árvores com auxílios de rastelos, vassouras, sacos de lixos, luvas, facões, canoa para retirada do lixo dentro da represa, pá carregadeira e caminhão para o transporte de lixo para local apropriado; (3) Confecção de placas de sensibilização feitas de madeiras recolhidas em serraria, utilizando tintas, pincéis e arames recozidos.

A terceira e última etapa, se realizou em novembro de 2019 com uma pesquisa qualitativa com 10 (dez) perguntas semiestruturadas (impressas em folhas A4) com 12 (dozes) agentes que estiveram presentes na realização de todas as ações do projeto de revitalização sobre a percepção ambiental, com a faixa etária entre os indivíduos de 18 a 52 anos. Para preservar a identidade dos sujeitos participantes, optou-se por substituir os nomes por algarismos alfanuméricos da seguinte maneira: Agente 1 (A1), Agente 2 (A2), Agente 3 (A3) e assim consecutivamente.

A pesquisa qualitativa possui como objetivo observar e interpretar a realidade estudada. Esta pesquisa utiliza procedimentos metodológicos, buscando explicações e alternativas que não precise de previsões, permanecendo critérios de confiança nas informações repassadas e credibilidade para a comunidade científica (Pádua, 2012).

As perguntas contidas no questionário foram: 1. O que você considera como maior problema ambiental da região? 2. O que você entende sobre educação ambiental? 3. Você considera que a revitalização do Eco Park é um meio de educação ambiental? Justifique. 4. Você acredita que as ações desenvolvidas no Eco Park podem causar mudanças na postura dos moradores e demais pessoas que utilizam a área? 5. Porque você quis participar do projeto? 6. Quais os aprendizados que foram the proporcionados por esse projeto de revitalização? 7. Quais benefícios foram proporcionados pelas ações de revitalização do Eco Park? 8. Quais aspectos da revitalização que você considera mais importantes para melhorar os aspectos do parque? 9. Faça sugestões viáveis para promover sensibilização ambiental com os moradores do entorno do Eco Park e demais pessoas que utilizam a área. 10. Você considera que ações de 
sensibilização ambiental em áreas urbanas incentivam no desenvolvimento sustentável do município?

Após a coleta dos questionários, analisaram-se às dez perguntas, colocando as respostas em uma tabela no Microsoft Excell 2017. Para análise dos dados das respostas, utilizou-se a metodologia Análise de Conteúdo. A Análise de Conteúdo é uma metodologia capaz de enriquecer o que se busca, sendo uma confirmação ou uma informação dependendo da interpretação do objetivo do estudo (Bardin, 2012). Segunda a autora, com a metodologia é possível dividir o texto em alguns temas principais (categorias) dos resultados obtidos da pesquisa, podendo se ampliar em subtemas (subcategorias) a critério do(s) autor(es).

Por meio da análise dos dados coletados, foram identificadas 5 (cinco) categorias: Problemas ambientais da região; A educação ambiental e a revitalização do Eco Park; A participação no projeto e as mudanças por meio das ações desenvolvidas; Aprendizagem, benefícios e melhoria para o parque; Desenvolvimento sustentável e sensibilização.

\section{Contextualização e ações desenvolvidas pelo projeto de revitalização}

A Primeira denominação do núcleo de povoação que originou o município de Confresa foi Vila Tapiraguaia, uma fusão dos termos Tapirapé e Araguaia. Tratava-se de referência geográfica aos Rios Tapirapé e Araguaia (Ferreira, 2017). Com passar dos tempos, as pessoas começaram a chamar o local de Confresa em alusão a Colonizadora Frenova Sapeva, que foi acatada oficialmente (IBGE, 2020).

O município de Confresa está localizado na Microrregião Norte do Vale do Araguaia inserido no Estado do Mato Grosso, possuindo imensas extensões de terras que servem para o plantio de grão e pastagens (Cessa, 2013). Segundo dados do IBGE (2020), o município possuía em 2010 um total de 25.124 habitantes e a estimativa para o ano de 2019 em torno de 30.933 habitantes.

O parque utilizado como objeto do estudo está localizado no município de Confresa no loteamento Imperial Eco Park, e começou a ser construindo em 2014 para atender a comunidade do local com área de lazer e descanso, contando com duas represas e espaço para pratica de atividades físicas. A área do parque é de aproximadamente $56.058 \mathrm{~m}^{2}$, cuja visão aérea está ilustra a Figura 1. 
Figura 1: Visão aérea do parque por satélite.

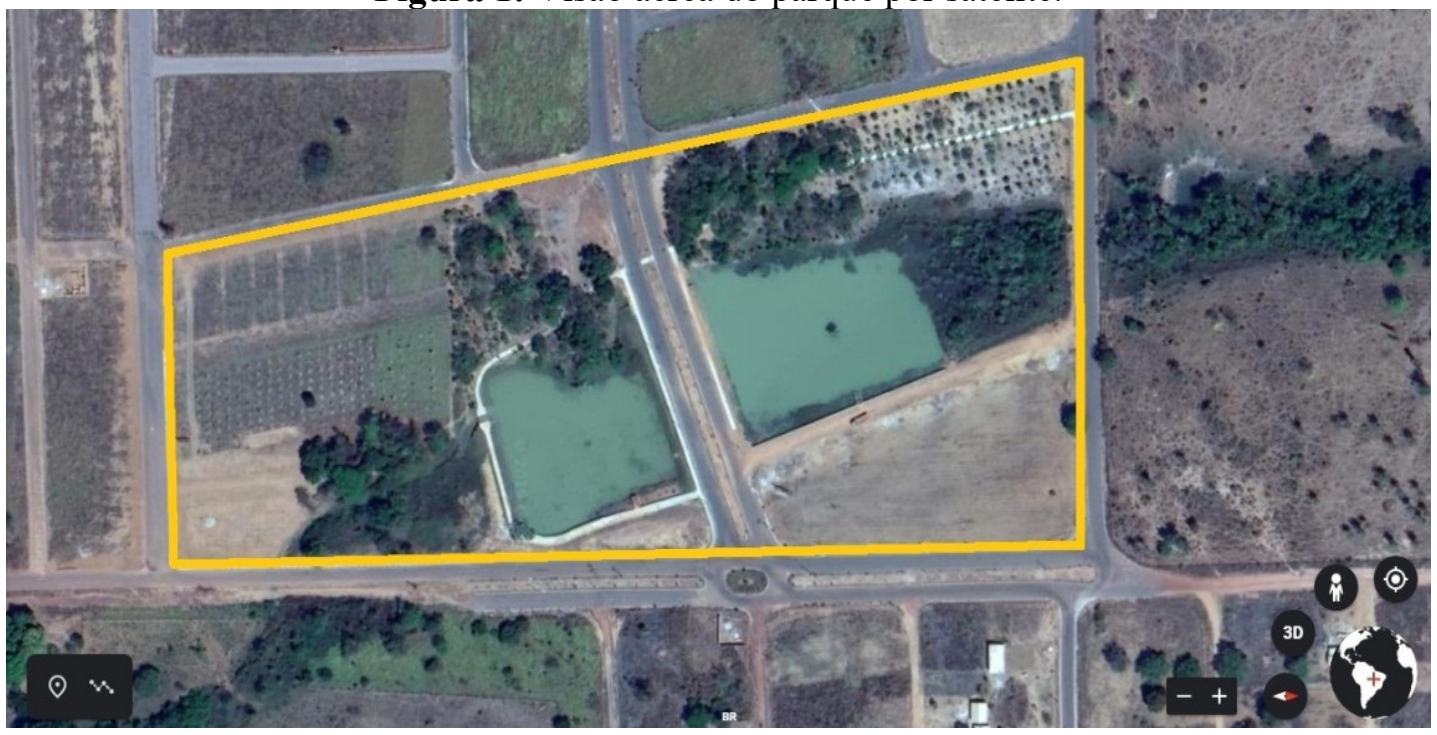

Fonte: Google Maps (2019).

Sendo uma área com bastantes espécies arbóreas com a função de preservar os recursos hídricos, é imprescindível que se crie ações e práticas educativas voltadas à EA para que não ocorram danos severos de degradação de tais recursos. O parque também se mostra muito suscetível para a realização de aulas práticas, palestras de preservação e pesquisas para desenvolver em seu entorno, possuindo muitas espécies nativas.

O projeto se inicializou com uma primeira reunião na segunda quinzena do agosto de 2019 na Câmara Municipal de Confresa. A reunião contou com a participação dos agentes ambientais voluntários, agentes da Ong Engajamundo, secretário do meio ambiente e agricultura, secretário do turismo, secretária da cultura, professores, estudantes, policiais civis, servidores da prefeitura e a equipe da televisão local RNA TV.

Durante a primeira reunião, foram elencados alguns problemas encontrados no parque: o local se encontrava com bastante lixo espalhado por toda a área e dentro das duas represas, churrasqueiras improvisadas feitas de tijolos, carência de recolhimento do lixo que era depositado nas lixeiras, ausência de iluminação pública, tráfico e consumo de drogas no período noturno e poluição sonora principalmente nos finais de semana.

A partir dos principais problemas do parque elencados fez-se um planejamento das atividades para realizar em 2019 pelos agentes. Assim, às duas ações iniciais para ajudar a melhoria da qualidade e infraestrutura do parque foram: limpeza do local e confecção de placas de sensibilização. 
No decorrer da primeira semana do mês de outubro, a associação dos agentes ambientais voluntários com a equipe de Secretaria de Obras e a equipe da Secretaria de Planejamento começaram fazendo a poda dos galhos das árvores e retirando galhos secos encontrados com auxílio de materiais de limpeza com facões e motosserras (Figuras 2A e 2B).

A equipe do projeto focou na retirada dos galhos mais baixos das árvores, facilitando assim a elaboração das próximas ações e também a caminhada por todo o parque pelos moradores. Foram retirados, ainda no início, os galhos secos e árvores mortas do meio do parque para ser levado a uma área de floresta encontrada no final do loteamento, pois a permanência do mesmo poderia trazer problemas futuros para a população, tal como: abrigar animais peçonhentos em um local de grande circulação de pessoas.

Após a retirada dos galhos e árvores mortas foi realizada a limpeza do local, onde se encontrava em uma situação de verdadeiro descaso pelos moradores da região que faziam churrasqueiras improvisadas de tijolos e uma grande quantidade de lixos espalhados na área (Figuras 2C e 2D).

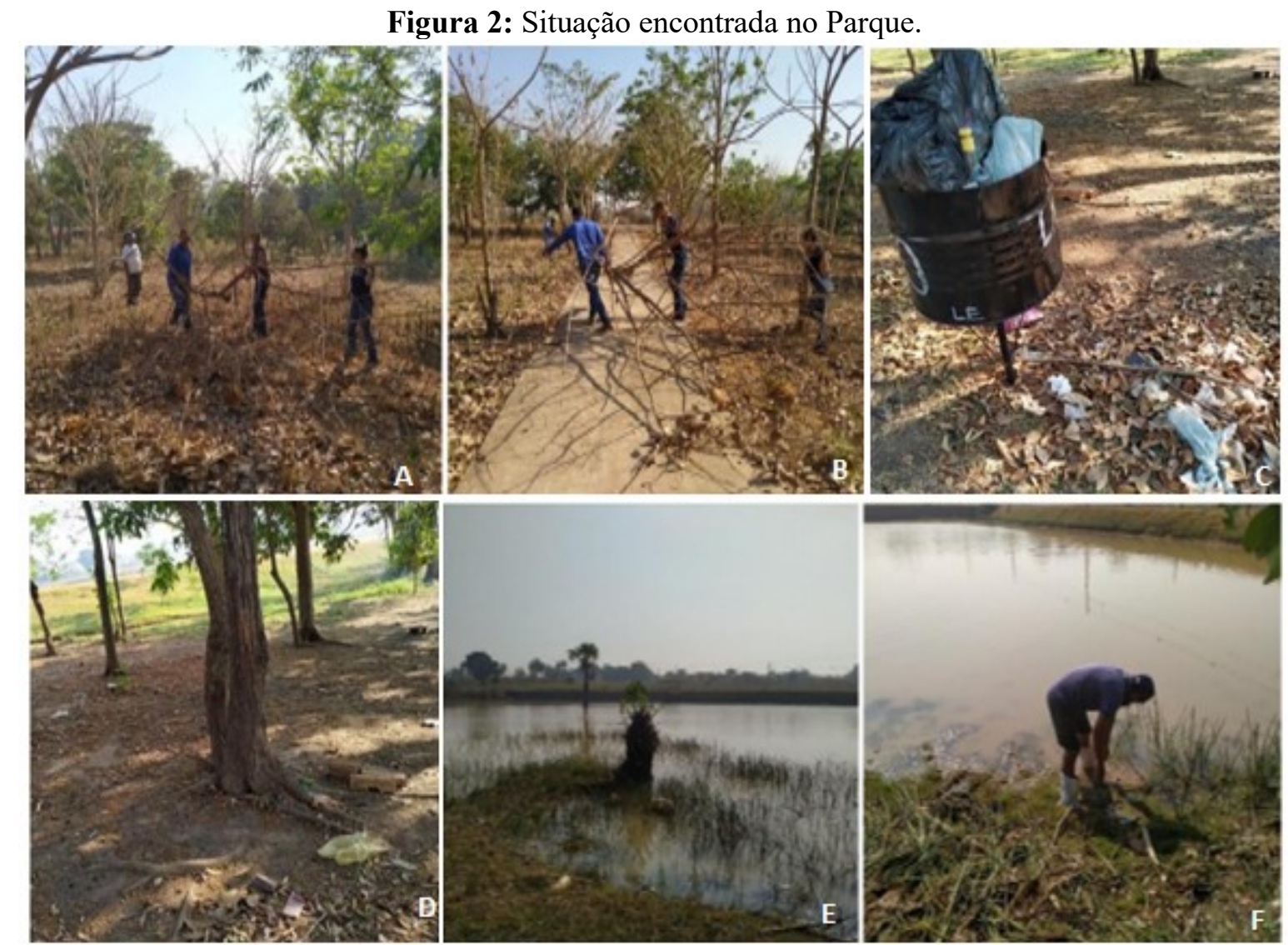

Fonte: acervo pessoal (2019). 
Dentro do parque, a quantidade de lixo encontrado era uns dos principais problemas no local, pois apenas duas lixeiras estavam presentes para a coleta. Foi possível observar que a coleta do lixo não ocorre semanalmente, agravando mais o problema. Assim, na ação de coleta foi preciso vasculhar com auxílio de rastelos e vassouras toda a serapilheira para encontrar resíduos sólidos entre a serapilheira e até mesmo ações dentro das represas.

Nos dias seguintes, os agentes ambientais voluntários de Confresa entraram em ação dentro da represa do parque, retirando lixos, tais como: sacolas, garrafas PET e de alumínio, roupas, fraudas descartáveis e capim (Figura 2E e 2F), essa atividade contou com a participação da Secretaria do Meio Ambiente que disponibilizou uma canoa para facilitar o acesso.

Foi possível recolher uma grande quantidade de resíduos dentro das represas, podendo prejudicar algumas espécies de peixes presentes no parque e principalmente no fluxo de água.

Por último, aconteceu o dia "D", que reuniu a Secretaria Municipal de Planejamento, Secretaria Agricultura e Meio Ambiente, Secretaria de Educação, Secretaria de Obras e Secretaria de Cultura, Sindicato Rural, Conselho Tutelar, Escola Municipal Tiradentes, ONG Engajamundo e a Associação dos Agentes Ambientais, além dos moradores da cidade para terminar a limpeza, contado com ajuda de uma pá carregadeira para retirada do lixo e dos galhos/pedaços das árvores do local e um caminhão para o transporte do mesmo a um local. Todo lixo encontrado no local foi colocado em sacos de plásticos pretos e destinados para o "Lixão" do município. Cabe ressaltar que o município ainda não possui um aterro sanitário para a deposição correta do lixo.

Nesse dia "D", alguns agentes pintaram os troncos das árvores com cal, no processo chamado de caiação. Mas por falta de planejamento e diálogo nessa questão não se verificou os impactos negativos de tal prática, pois antigamente acreditava-se que ao pintar os troncos das árvores estaria protegendo contras agentes patogênicos, porém não traz nenhum benefício para as plantas, apenas prejudicando as trocas gasosas.

A EA utiliza estratégias relevantes como as placas informativas e de sensibilização, desde que se enquadram no perfil ambiental e de envolvimento com a comunidade destinada, identificando os problemas de uma área, a manutenção e de como ocorreram à mudança por essas estratégias (Dias, 2004). 
A terceira ação do projeto foi à confecção de placas de sensibilização de preservação do meio ambiente. Nesta ação utilizaram-se pedaços de madeiras doadas por uma serraria da cidade, tinta acrílica branca, pincéis marcadores pretos e azuis e furadeira.

Em cada placa foram escritas frases encontradas na "internet" e colocadas nas árvores com auxílio de arame recozido. Optou-se por colocar as placas penduradas nas árvores ao invés de estacas e não utilizar pregos prejudicando assim os vasos condutores de nutrientes

Com essa ação, buscou-se uma maior sensibilização das pessoas que visitam o parque no que diz respeito a utilizar o espaço de forma consciente, a jogar o lixo gerado em local correto, a conservação dos recursos hídricos, a importância das espécies arbóreas e principalmente a ações em prol da EA.

\section{Resultados e Discussões}

Conforme descrito na metodologia, foram entrevistados 12 agentes que atuaram no projeto de revitalização. Diante das respostas coletadas, foram identificadas 5 (cinco) categorias de análise por meio das questões contidas no instrumento de coleta de dados: Problemas ambientais da região; A educação ambiental e a revitalização do Eco Park; A participação no projeto e as mudanças por meio das ações desenvolvidas; Aprendizagem, benefícios e melhoria para o parque; e Desenvolvimento sustentável e sensibilização, conforme Quadro 1:

Quadro 1: Organização dos dados da pesquisa.

\begin{tabular}{|c|c|}
\hline Pergunta(s) do questionário & Categorias \\
\hline $\begin{array}{l}\text { 1. O que você considera como maior problema ambiental } \\
\text { da região? }\end{array}$ & Problemas ambientais da região \\
\hline $\begin{array}{l}\text { 2. O que você entende sobre educação ambiental? } \\
\text { 3. Você considera que a revitalização do Eco Park é um } \\
\text { meio de educação ambiental? Justifique. }\end{array}$ & $\begin{array}{l}\text { A educação ambiental e a } \\
\text { revitalização do Eco Park }\end{array}$ \\
\hline $\begin{array}{l}\text { 4. Você acredita que as ações desenvolvidas no Eco Park } \\
\text { podem causar mudanças na postura dos moradores e } \\
\text { demais pessoas que utilizam a área? } \\
\text { 5. Porque você quis participar do projeto? }\end{array}$ & $\begin{array}{l}\text { A participação no projeto e as } \\
\text { mudanças por meio das ações } \\
\text { desenvolvidas }\end{array}$ \\
\hline $\begin{array}{l}\text { 6. Quais os aprendizados que foram lhe proporcionados } \\
\text { por esse projeto de revitalização? } \\
\text { 7. Quais benefícios foram proporcionados pelas ações de } \\
\text { revitalização do Eco Park? } \\
\text { 8. Quais aspectos da revitalização que você considera } \\
\text { mais importantes para melhorar os aspectos do parque? }\end{array}$ & $\begin{array}{l}\text { Aprendizagem, benefícios } \\
\text { melhoria para o parque }\end{array}$ \\
\hline
\end{tabular}


9. Faça sugestões viáveis para promover sensibilização ambiental com os moradores do entorno do Eco Park e demais pessoas que utilizam a área.

10. Você considera que ações de sensibilização ambiental em áreas urbanas incentivam no desenvolvimento sustentável do município?

Desenvolvimento sustentável e sensibilização

Fonte: Elaborada pelos autores (2019).

A partir das categorias elencadas surgiram subcategorias, conforme no Quadro 2.

Quadro 2: Subcategorias encontradas.

\begin{tabular}{|l|l|}
\hline \multicolumn{1}{|c|}{ Categorias } & \multicolumn{1}{c|}{ Subcategorias } \\
\hline Problemas ambientais da região & Falta de conscientização da população \\
\cline { 2 - 2 } & Desmatamento e problemas relacionados \\
\cline { 2 - 2 } & Destino do lixo \\
\hline \multirow{2}{*}{$\begin{array}{l}\text { A educação ambiental e a revitalização do } \\
\text { Eco Park. }\end{array}$} & O papel da educação ambiental \\
\cline { 2 - 2 } & Impactos ao meio ambiente \\
\cline { 2 - 2 } & $\begin{array}{l}\text { Construção do conhecimento mediante ao } \\
\text { projeto de revitalização }\end{array}$ \\
\hline $\begin{array}{l}\text { A participação no projeto e as ações } \\
\text { desenvolvidas. }\end{array}$ & A importância do projeto \\
\cline { 2 - 2 } & Mudanças acontecidas após as ações \\
\hline $\begin{array}{l}\text { Aprendizagem, benefícios e melhoria para } \\
\text { o parque. }\end{array}$ & O cuidado com o meio ambiente \\
\cline { 2 - 2 } $\begin{array}{l}\text { Desenvolvimento sustentável e } \\
\text { sensibilização }\end{array}$ & A principal ação desenvolvida \\
\cline { 2 - 2 } & Fiscalização \\
\cline { 2 - 2 } & Ações no espaço escolar \\
\hline
\end{tabular}

Fonte: Elaborada pelos autores (2019).

Cada uma das categorias e subcategorias serão apresentadas e discutidas na sequência.

\section{Problemas ambientais da região}

A EA busca elaborar métodos e técnicas dentro e fora do ambiente escolar que facilite na formação da consciência a respeito da gravidade e a necessidade sobre os problemas ambientais (Carvalho et al., 2016). Com relação à categoria obtida da pergunta 1 (um), buscou identificar por meio dos agentes o que eles consideravam o maior problema da região, assim da categoria problemas ambientais da região surgiu as seguintes subcategorias: falta de sensibilização da população, desmatamento e problemas relacionados e destino do lixo.

No que se refere à subcategoria: falta sensibilização da população obtiveram-se duas respostas: A4: "Falta de conscientização das pessoas". A6: "A falta de consciência e atitude de todos que vivem na região". 
É evidente nas respostas alcançadas que a região mostra um déficit no que abrange a preocupação e preservação e conservação com o meio ambiente, pois ocorre a degradação de vários locais no município. Sendo preciso à elaboração de mais ações envolvendo a EA e a população, pois as questões ambientais encontram-se em extrema urgência de serem debatidas. Portanto, a EA busca maneiras conscientes para melhoria e proteção do meio ambiente e prevenção contra desastres ambientais (Carneiro et al., 2016; Fonseca, 2016).

Diante do questionamento dos problemas ambientais da região, as repostas dos agentes A4 e A6 se mostraram adjacentes. Deste modo, cabe acentuar que a grande preocupação com os problemas ambientais é um dever de todos. Sendo que a EA se entende dos espaços formais da educação ao contato com meio ambiente, é imprescindível que aconteça mais ações voltadas para a conscientização ambiental, principalmente no âmbito escolar, visto que formando cidadãos conscientes presenciamos a criação de um futuro melhor (Hofstatter et al., 2016; Rodrigues \& Sahab, 2018).

A respeito ao desmatamento e problemas relacionados, sendo tais problemas os mais apontados na pesquisa, algumas respostas dos agentes foram: A7: “O maior problema da região está ligado com assoreamento dos rios e desmatamentos. $\mathrm{Na}$ área urbana a população sofre com o abastecimento de água". A2: “Desmatamento e assoreamento". A9: "Queimadas, desmatamento e assoreamento".

Na percepção dos agentes diante da subcategoria fica evidente que o principal problema ambiental enfrentado pela região é o desmatamento, podendo ter impactos nos demais, como o assoreamento dos rios, abastecimento de água e queimadas. Segundo o Projeto de Monitoramento do Desmatamento na Amazônia Legal por Satélite (PRODES), em 2018 a área desmatada do município de Confresa-MT equivalia à $3906.8 \mathrm{~km}^{2}$, mostrando um crescimento de $0,73 \%$, desde 2016 .

Assim, como abordam os agentes A2, A7 e A9 a respeito dos assoreamentos dos rios, Rubira (2016) aponta que tal problema é oriundo principalmente da degradação das áreas verdes para crescimento populacional. Cabe ressaltar ainda que além do crescimento populacional a degradação das áreas verdes é estimulada para a produção da agricultura e pecuária.

O desmatamento ocasionado principalmente para a produção de grãos e a pecuária assumiu papel de destaque como principal problema da região, que além de afetar a fauna e flora, o desmatamento agrava vários outros problemas citados pelos agentes, tais como: 
queimadas, assoreamento dos rios e o abastecimento de água para a área urbana e outros problemas que não foram abordados: altas temperaturas, diminuição das chuvas, desgaste dos solos e redução da umidade relativa do ar.

Como relatados pelos agentes, o município ainda sofre com a escassez de água entre os meses de maio a outubro, devido que o Córrego Cacau como a principal fonte de abastecimento se encontra desprotegido de mata ciliar ocasionado principalmente pelo desmatamento.

Na subcategoria destino do lixo os agentes relataram alguns problemas: A11: "Destino incorreto dos resíduos sólidos”. A12: “[...] queimadas de lixo nas áreas urbanas”.

A10: O descarte inadequado do lixo urbano e principalmente o lixo da zona rural (pelo menos na urbana ainda tem coleta seletiva mesmo não tendo um aterro sanitário adequado). Descarte inadequado de resíduos de sólidos de defensivos agrícolas [...].

Conforme Carvalho et al. (2016) e Budzilo (2016), o consumo exagerado da sociedade leva a uma desordem na produção e no destino do lixo, causando vários problemas a população. No município o destino dos resíduos sólidos é realizado no "Lixão" a céu aberto sem nenhum tratamento, podendo contaminar córregos, rios e represas, destaca-se que constantemente ocorre a queimadas dos resíduos no local. Ainda como relata o agente A12, é perceptível que os moradores queimam resíduos sólidos dentro do município, ocasionando prejuízos enormes para a população devido à grande quantidade de fumaça produzida e contaminando o ar e provocando doenças respiratórias.

De acordo com o agente A10, na zona rural é feito o descarte inadequado dos resíduos oriundos dos defensivos agrícolas, tal problema pode acarretar principalmente na contaminação dos lençóis freáticos que compromete a vida dos humanos e dos animais.

Uma pesquisa desenvolvida por Ostrovski e Ostrovski (2015), com estudantes do curso de graduação em Engenharia de Alimentos na Universidade Tecnológica Federal do Paraná (UTFPR) Campus Medianeira, mostra resultados semelhantes em comparação aos agentes deste trabalho sobre os problemas ambientais na cidade de Medianeira-PA, foram elencados pelos estudantes: falta de água, queimadas, desmatamento e lixo na rua.

Os resultados quanto aos conhecimentos dos agentes sobre os problemas ambientais mostraram uma grande compressão sobre o tema no município. Diante disso, é possível que mais ações e práticas possam ser desenvolvidas na região para que aconteça uma sensibilização pelo meio ambiente. Por essa razão Barbosa et al. (2017) afirmam que para que ocorra uma 
mudança no comportamento e conscientização a respeito dos problemas ambientais é preciso ter uma união entre os seres humanos e o meio ambiente em que eles se encontram inseridos.

Portanto, essas concepções mostram que a EA estimula na visão dos problemas ambientais, a resolução dos problemas reais e a concretização de projetos que visam prevenilos (Cruz et al., 2016). Assim, ações de coleta seletiva do lixo, redução no desperdício de água e outras atitudes para a proteção do meio ambiente, são ações que devem estar presentes em cada indivíduo, havendo uma mudança comportamental (Carneiro et al. 2016).

Além dos problemas elencados, os agentes apontaram sobre as queimadas rurais, que ocorrem principalmente entre os meses de setembro a outubro, deixando o ar poluindo e agravando casos de pessoas com problemas respiratórios e também queimadas urbanas de lixo que acontecesse em vários períodos do ano.

\section{A educação ambiental e a revitalização do Eco Park}

“A educação é apontada como uma das ferramentas imprescindíveis na iniciativa de buscar orientar humanidade para que possa tomar outro rumo, um novo destino" (Pitanga, et al., 2016, p. 145). O projeto de revitalização teve como objetivo principal promover a EA no parque, deste modo a segunda categoria sobre a EA e a revitalização do Eco Park emergiu das perguntas 2 (dois) e 3 (três). Dentro da categoria foi possível identificar as seguintes subcategorias: O papel da educação ambiental, impactos ao meio ambiente e construção do conhecimento mediante ao projeto de revitalização.

As repostas dos agentes sobre o papel da educação ambiental foram: A2: "É a educação que forma indivíduos preocupados com o meio ambiente. A partir daí busca a preservação do meio em que vive". A3: "Entendo que é toda forma de educação que visa à conscientização das pessoas para que busquem viver de forma mais sustentável". A12: "É uma educação que visa melhorar o meio ambiente".

A9: É um processo responsável que contribuem para que os indivíduos construam conhecimento, atitudes relacionando com a preservação/conservação do meio ambiente, e é uma ação educacional para adquirir a consciência ambiental que precisamos para construir uma sociedade mais igualitária garantida um futuro melhor para as futuras gerações.

A10: Formação socioambiental de um indivíduo, onde ele constrói valores sociais individuais e coletivos, habilidades de conservação do meio onde ele vive, assim como 
o uso comum do povo, evitando desperdícios de alimentos, reduzindo o consumo de coisas desnecessárias e a quantidade de lixo produzido além de reciclar.

Com relação às repostas obtidas, os agentes possuem uma visão ampla ligada ao papel da EA em relação à natureza e meio ambiente, descrevendo que é um processo que se constrói conhecimento sobre a proteção e melhorias. Foi constatado também pelos agentes à preocupação em tornos dos problemas ambientais, por exemplo, o consumo exagerado, desperdício de alimentos e a quantidade de lixo produzido.

Assim como o A3 evidencia que a EA compreende a toda forma de educação que visa à sensibilização das pessoas, Hofstatter et al. (2016), debatem que a EA não se restringe aos espaços formais da educação, mas por meio da escola é possível promover uma formação comprometida com as causas ambientais que será apresentada nas demais áreas.

Segundo o A10, a EA possui o papel de formação socioambiental de um indivíduo, é importante ressaltar que essa formação não impõe hábitos e modelos comportamentais, os autores Cruz et al. (2016), destacam que cada cidadão construa atitudes voltadas a preservação do meio ambiente. Carvalho et al. (2016) nesse contexto, enfatiza que é importante que EA desperte o sentimento de que somos corresponsáveis pelas mudanças de atitudes de preservação e na promoção de um novo tipo de desenvolvimento, o desenvolvimento sustentável.

Na segunda subcategoria sobre os impactos ao meio ambiente, os agentes relataram: A4: "Ensinar as pessoas que as ações feitas por elas têm impactos no meio ambiente, quais seriam como reverter ou cuidar para não piorar". A1: “É uma forma de conscientizar as pessoas sobre os impactos negativos que elas causam no meio ambiente e como mudar isso".

Nas respostas dos agentes A1 A4, relata-se que as ações dos seres humanos podem ter impactos negativos ao meio ambiente e que se não houver uma mudança significa teremos um agravamento dos problemas ambientais no futuro. Assim, no trabalho desenvolvido por Junior e Sá (2017), ressaltam que a preocupação do século XVI é em torno das questões ambientais, Santos e Gardolinski (2016), ainda afirmam que os impactos ambientais são devido à exploração dos recursos naturais, consumo desenfreado e a falta de cuidados com o destino de resíduos sólidos.

Deste modo, faz-se necessário que todos reflitam sobre os impactos causados pelas suas ações ao meio ambiente e procurar maneiras de utiliza-lo sem promover a degradação. A respeito da prevenção contra os desastres ambientais, Sulaiman e Aledo (2016), destacam que é 
preciso conhecer para prevenir por meio de conhecimentos científicos em prol do desenvolvimento sustentável. Essa mudança não é apenas a transferência de conhecimentos, é preciso um compromisso com a transformação da sociedade e no pensamento crítico consciente, livre e responsável com o mundo a sua volta (Carvalho et al., 2016).

A terceira subcategoria sobre construção do conhecimento mediante ao projeto de revitalização, os agentes apontaram: A11: “[...] a revitalização é uma forma de mostrar a todos que um ambiente limpo, bem cuidado e preservado, melhora a qualidade de vida de todos". A8: “[...] é uma ação comunitária que atinge e educa pessoas de todas as áreas da cidade, considerando uma consciência cidadã". A9: "Sim, este é um importante local de preservação ambiental, onde a população tem um espaço público voltado para a convivência harmônica com o meio ambiente".

A2: “[...] qualquer ação já está sim promovendo um aprendizado, e a revitalização do Eco Park está totalmente voltada para a essa educação ambiental”. A3: “[...] foi um espaço de educação informal e de troca de experiências entre todos os envolvidos. Além de que o contato com o local proporcionou uma sensação de pertencimento".

Foi percebido que as respostas obtidas pelos agentes que o projeto de revitalização cumpriu com o seu objetivo de promover a EA, pois, por meio das ações desenvolvidas foi possível a troca experiências sobre o processo de preservação do parque, sendo proibida a retirada de recursos naturais. Nesse contexto, Cruz et al. (2016) abordam que as propostas da EA é um processo que exige uma ação coletiva e ações na transformação do sujeito, construindo uma visão crítica em relação ao homem e ao meio ambiente.

Deste modo, A EA Construtivista que busca desenvolver projetos e ações à prevenção aos problemas ambientais (Sorrentino \& Trabjer, 2007), Guimarães (2016) acredita que por meio dos conhecimentos nas ações e no desenvolvimento ocorre uma transformação da sociedade na compreensão da gravidade dos problemas socioambientais.

\section{A participação no projeto e as mudanças por meio das ações desenvolvidas}

A EA tem como missão criar um espirito crítico para a cidadania por meio de escolhas conscientes e responsáveis (Leite et al., 2016). Assim, a terceira categoria sobre a participação no projeto e as mudanças por meio das ações desenvolvidas surgiu das perguntas (4) quatro e 
(5) cinco. A partir da elaboração da categoria foi possível evidenciar as seguintes subcategorias: A importância do projeto e mudanças acontecidas após as ações.

Sobre a importância do projeto, os relatos dos agentes foram: A3: "Achei o projeto muito importante para a melhoria dos poucos espaços de lazer da cidade e para proteção da fauna do local que estava prejudicada devido à grande quantidade de lixo". A11: "Eu participei do projeto, pois é muito importante que todas as pessoas assumam a sua responsabilidade social". A1: "Eu participei porque existia a necessidade de se fazer algo em relação àquele local e também por influência de amigos".

A9: Ansiava por estar revitalização geral, manutenção, algo que nunca ocorreu desde a sua inauguração. Um local de grande relevância, por ser uma área de preservação permanente (APP), utilizando inclusive como referência na promoção da educação ambiental.

A10: Porque acredito que uma ação transforma a forma como as pessoas no entorno visualizam aquela área tão promissora. Para muitos lá é um local de lazer, no entanto, uma parte não entende isso e pensa que lá é somente um depósito de lixo. Acredito que dando o exemplo pelo menos uma pessoa será atingida de forma positiva e quem sabe essa pessoa também resolva fazer uma ação e assim mais pessoas vão sendo tocadas uma gentileza gera muitas outras gentilezas.

De acordo com as respostas obtidas, fica evidente que ações desenvolvidas foram importantes para a melhoria e revitalização do parque e que nos pensamentos dos agentes que participaram do projeto já havia uma preocupação a respeito do local, mas precisava-se de uma iniciativa para que tais ações fossem desenvolvidas. Assim, a partir das ações e o conhecimento adquirido, espera-se que os agentes possam elaborar mais propostas que atinja grande parte da sociedade. Faz-se necessário à elaboração de ações críticas e inovadoras em relação às questões ambientais, objetivando a formação de cada cidadão (Carvalho et al., 2016).

O parque nunca havia passado por uma revitalização ou reforma, o mesmo se encontrava bastante sujo e com lixo espalhado por toda sua extensão, inclusive dentro das represas, o A9 aborda que ansiava por esta revitalização, pois nunca ocorreu nenhuma ação desde inauguração, destacando que o parque é de grande relevância para a sociedade, sendo uma Área de Preservação Permanente (APP), servindo de referencial para a EA, assim todos que frequentam o parque ou que participaram do projeto tenham uma responsabilidade social com o meio ambiente.

$\mathrm{Na}$ subcategoria mudanças acontecidas após as ações desenvolvidas, os agentes apontaram: A2: "Depois da ação que foi feita no Eco Park, as pessoas não jogam mais lixo como 
antes (influenciadas pelas placas de sensibilização que foram ali colocadas)". A12: "Porque por meio de pequenas ações conseguimos trazer melhorias para toda a população".

A9: [...] está revitalização é super importante para a população do Eco Park e outros bairros, pois é um local onde diversas atividades podem ser desenvolvidas, por exemplo, caminhadas e outros exercícios, e também, um ponto de encontro da comunidade, atendendo desde crianças até os idosos.

A3: "Ao ver que as pessoas estão cuidando do lugar os outros visitantes do parque podem seguir o exemplo começando a melhorar suas atitudes". A8: "pois demonstra uma preocupação coletiva com a problemática de revitalizar uma área verde". A11: "Porém são necessárias ações mais pesadas em relação à fiscalização do local. Pois, se percebe que práticas de mau comportamento em relação ao uso do local permanecem”.

Em relação à subcategoria percebe-se que as ações desenvolvidas tiveram impactos na população do município como aborda o agente A2 sobre a importância de utilizar as placas de sensibilização, mas segundo o A11 ainda é preciso ter uma maior fiscalização do local. Além da fiscalização que é um fato importante para se considerar, Barbosa et al. (2016), colocam que seria necessário encontrar meios mais efetivo no espaço escolar, ou até mesmo fora da escola de promover ações continuas de preservação ambiental, por meio de leituras, projetos e tantas outras.

Tiveram duas respostas que se divergiram das demais dos agentes A1 e A5: A1: "Não, vejo a revitalização do Eco Park como uma ação conjunta. Muitas pessoas estavam ali só por status sociais e essa educação deve ser feita de outras formas". A5: "Não, porque quem auxiliou já tinha essa sensibilização para o meio ambiente, só exercitou o que já tinha”.

Diante disso, cabe ressaltar que essas pessoas que só participaram das ações para poder postar fotos nas redes sociais contribuíram com o processo e nas ações propostas, e por mais que os elaboradores do projeto já tivessem o entendimento sobre a EA, todos os agentes que participaram das ações teve algo para acrescentar, compartilhando com os demais.

\section{Aprendizagem, benefícios e melhoria para o parque}

Carneiro et al. (2016) abordam que nas últimas décadas as preocupações sobre os problemas ambientais vêm se intensificando, é preciso uma mudança de posturas ao equilíbrio para educar a sociedade. Assim, a quarta categoria que contempla a aprendizagem, benefícios e melhoria para o parque emergiu das perguntas 6 (seis), 7 (sete) e 8 (oito). Dentro 
da categoria se manifestou as seguintes subcategorias: Cuidado com o meio ambiente e a principal ação desenvolvida.

Na subcategoria, cuidado com o meio ambiente, os agentes abordaram: A5: "Precisamos entender a importância do trabalho em equipe, que precisamos ter mais contato com a natureza e que trabalhar sem esperar nenhum retorno financeiro, só pelo ato de colaborar, faz bem para a alma". A8: "Que quanto mais se preocupa em divulgar e sensibilizar as pessoas mais surge pessoas preocupadas com a causa".

A10: Que essas ações não devem ser só pontuais, elas têm que acontecer em forma de sensibilização nos outros setores, porque toda a cidade faz uso daquele espaço. Tem que ter aumento da divulgação publicitaria, não só nas redes sociais, mas também nas mídias. Foi uma ação que atingiu um quantitativo substancial de pessoas, que pôde ser visualizado nas postagens das redes sociais, onde a comunidade fazia elogios e agradecimentos às pessoas que realizaram a limpeza do parque. Fica claro que elas entendem a importância da ação, mesmo não participando.

A1: "Precisamos ter consciência de que jogar lixo em locais indevidos é ruim, precisamos ter educação ambiental e ter compromisso conosco de não jogar lixo em locais públicos". A2: "Que devemos guardar até uma embalagem de balinha, porque faz toda diferença”.

Percebe-se nessa categoria a ação de coletividade voltada a EA e o respeito ao meio ambiente. Os agentes elencaram que desenvolver ações da EA em grupo ajuda no processo de aprendizagem e que mais pessoas possam ser engajadas nas causas ambientais. Carvalho et al. (2016), debatem que cada indivíduo tem uma maneira de percepção e a partir dessa percepção cria-se programas de EA, que possa envolver e despertar mais pessoas na preservação ambiental.

Sobre a categoria a principal ação desenvolvida, foram relatadas as seguintes respostas: A3: "A limpeza do lixo na beira das represas e na serapilheira [...]". A6: "Sem dúvida nenhuma a limpeza e coleta de lixos [...]". A8: "A coleta de lixo e as placas de sensibilização com uma linguagem descontraída".

Partido do pressuposto das ações desenvolvidas os agentes citaram mais de uma ação: limpeza e coletas do lixo e as placas de sensibilização. Deste modo, é evidente que as ações elaboradas tiveram impactos para os agentes e ao meio ambiente. Pitanga (2016) aborda que nesse cenário, a EA é indispensável para uma integração de valores ambientais para garantir uma nova formação humana. A autora ainda enfatiza que é preciso uma nova postura na construção de sociedades ecologicamente equilibradas. 
A1: “As pessoas agora possuem um local mais limpo e mais organizado para passar aquele final de semana". A5: "O local ficou mais chamativo e convidativo para passar alguns momentos em família ou com amigos".

A10: "Ambiente mais aprazível e acolhedor param se passar uma tarde com amigos e familiares. O ambiente ficou afável para se fazer uma aula prática com estudantes das escolas locais. Mais famílias começaram a frequentar o local. Houve diminuição da poluição visual do local".

Nos estudos de Lima e Rocha (2016), os parques urbanos estão sempre ligados à preocupação de conservação, preservação e revitalização, pois esses espaços servem para manifestações culturais e artísticas. Deste modo, todos os indivíduos em torno do parque, perceberam os impactos positivos da revitalização, mas esses ganhos não podem ser temporários, é preciso que a comunidade adote ações e interesses ao longo prazo (Tanscheit, 2017).

A12: “O parque tornou-se mais agradável para as pessoas irem ao final de semana". A9: "Por meio das ações desenvolvidas no local, proporcionou que este espaço fosse utilizado por todos e na conscientização da importância de sua preservação".

\section{Desenvolvimento sustentável e sensibilização}

É importante que ações produzidas no presente tenham impactos positivos no futuro (Carneiro et al., 2016). Deste modo, a quinta categoria sobre o desenvolvimento sustentável do município e sensibilização, que aborda sugestões para promover a EA surgiu das perguntas 9 (nove) e 10 (dez). Dentro da categoria emergiu as seguintes subcategorias: fiscalização e ações no espaço escolar.

Referente à subcategoria falta de fiscalização, os agentes relataram: A1: "A contratação de fiscais que reprima pessoas que não utilizam corretamente aquela área". A11: “Ações de fiscalização ambiental em relação a queimadas urbanas de folhas e lixos, e lançamento de esgotamento sanitário".

Com as repostas obtidas, percebe-se que ainda precisa ser desenvolvidas mais ações em torno da EA, pois no município a fiscalização ambiental é precária na área do projeto e a respeito das queimadas urbanas. Assim é preciso uma maior preocupação com alguns problemas da região para que ocorra um desenvolvimento sustentável e uma sensibilização ambiental. 
Leite et al. (2016), acometem que a sensibilização pode acontecer em todo ambiente (ambiente escolar, bairros e comunidades), contribuindo para uma formação preocupada o desenvolvimento das sociedades de formas mais justas e consciente sem prejuízo ao meio ambiente.

Em relação à subcategoria ações no espaço escolar, os agentes apontaram: A10: “Ações formativas nas escolas, que trazem linguagem acessível para o estudante, pois eles são os maiores replicadores de informações que podem agir em favor daqueles que encabeçam o processo de revitalização do parque". A12: "Elaborar mais ações de sensibilização principalmente nas escolas". A6: "Envolver as escolas, a secretaria de saúde por meio dos agentes de saúde, falando e fazendo ações que desperte essa tomada de consciência, algo esse cuidar".

Nesta subcategoria é evidenciado pelos agentes que para ocorrer uma maior sensibilização ambiental é preciso desenvolver ações nos espaços formais de educação. Assim Barboza et al. (2016), destacam que para que a escola consiga trabalhar a sensibilização ambiental, faz se necessário que se tenha políticas institucionais diárias sobre a preservação e conservação ambiental, uma vez que a abordagem de EA em alguns momentos têm sido ineficientes para mudanças na sociedade.

No estudo desenvolvido por Figueiredo (2016), mostra que ações em prol da EA já vêm acontecendo no município de Confresa-MT, como é o caso da Escola Estadual Sol Nascente. Localizada na zona rural, a escola possui local apropriado para o destino do lixo com lixeiras seletivas e por meio do projeto Mais Educação, os estudantes realizam a arborização do local e a construção de uma horta, incentivando a uma alimentação saudável e a não utilização de substâncias que prejudicam o meio ambiente para a produção de alimento.

Na Escola Estadual Sol Nascente, os professores promovem debates sobre as questões ambientais, tornando possível com essas discussões preparar aulas que possam trabalhar a EA na escola, fortalecendo assim uma aprendizagem de qualidade (Silva, 2016).

Deste modo, o âmbito escolar como apresentado na subcategoria, possui a responsabilidade de desenvolver ações voltadas a EA, encaminhando os estudantes a serem ativos na conservação do meio ambiente por meio de atividades artísticas, experiências práticas, atividades fora de sala de aula e projetos (Leite et al., 2017). Nesse contexto Barboza et al. 
(2016), abordam que as práticas da EA se tornam necessárias no ambiente escolar, pois é uma estratégia promissora na formação cognitiva das crianças e dos adolescentes.

Outras ações apontadas pelos agentes para ajudar no processo de sensibilização foram à implantação de placas de identificação das espécies arbóreas do parque, lixeiras ecológicas e coletores de resíduos, entregar de panfletos e oficinas de materiais recicláveis. Assim é importante que no espaço institucional e fora aconteçam mais ações voltadas para a EA no parque e no município.

Cabe destacar ainda que Secretaria Municipal de Agricultura e Meio Ambiente em parceria com o Ministério Público, EMPAER, IFMT, UNEMAT e INCRA, estão discutindo propostas de intervenção ambiental para serem elaboradas no projeto "Cacau Verde" que visa a conservação do principal córrego que abastece o município de Confresa-MT, o mesmo se encontra desprovido de matar ciliar (Governo de Confresa, 2020).

\section{Considerações Finais}

O presente estudo teve como objetivo descrever as percepções dos agentes que atuaram na revitalização do Eco Park sobre a EA envolvida no projeto. Dentro desse contexto realizou uma pesquisa de cunho qualitativo com 10 (dez) perguntas semiestruturadas envolvendo desde os problemas ambientais da região até sugestões para promover a sensibilização ambiental.

A EA sendo um instrumento de melhoria para o meio ambiente, também tem o papel de apontar os problemas e como solucioná-los. Nesse sentido, os agentes mostraram um grande conhecimento em relação à percepção da EA, dos problemas ambientais: a falta de conscientização, desmatamento e destino do lixo e a compressão de sustentabilidade. Assim, a análise permitiu uma maior aproximação da participação do homem com a natureza, despertando novos comportamentos para os que atuaram no projeto e para aqueles que visitam o parque.

Os agentes destacaram bastante o desmatamento como principal problema regional. Deste modo, é questionado que se pensem em ações focada na EA para à mitigação dos problemas dentro das escolas, sendo possível a parceira com os Órgãos Públicos da região. Ainda foi possível observar uma preocupação por parte dos agentes para se desenvolver mais ações e sugestões de melhoria, como a implantação de placas de identificação das espécies arbóreas, lixeiras ecológicas e oficinas de materiais recicláveis. 
Algumas ações são realizadas em escola do município de Confresa-MT para a promoção da EA como mostra o estudo. Assim, por meio do projeto de revitalização do Eco Park espera-se que mais ações de sensibilização e melhoria para o meio ambiente possam ser elaboradas e que essa pesquisa seja capaz de servir como base para uma mudança no pensamento crítico da população a respeito dos impactos ambientais e que mais estudo e ações possam ser realizados na área da $\mathrm{EA}$.

Deste modo, considera-se que a pesquisa possa influenciar nas práticas pedagógicas das escolas do município, realizando um trabalho de qualidade por meio de propostas trazidas pelos professores nos conteúdos a respeito do conhecimento e mudanças de comportamentos de ações voltadas para a EA.

\section{Referências}

Barboza, L.A.S.; Brasil, D.S.B; Conceição, G. S. (2016). Environmental perception of 6th and 9th grade students from a municipal school in Redenção, Pará State, Brazil/Percepção ambiental dos alunos do $6^{\circ}$ e do $9^{\circ}$ anos de uma escola pública municipal de Redenção, Estado do Pará, Brasil. Rev Pan-Amaz Saude, p. 11-20. Disponível em: $<\mathrm{http}$ //scielo.iec.gov.br/scielo.php?script=sci_arttext\&pid=S217662232016000400011\&lng=pt\&nrm=iso>. Acesso em: 26 Jan 2020.

Bardin, L. (2012). Análise de conteúdo. Edições 70. São Paulo.

Brasil (1999). Lei No 9795, de 27 de abril de 1999. Dispõe sobre a educação ambiental, institui a Política Nacional de Educação Ambiental e dá outras providências. Diário Oficial [da] República Federativa do Brasil. Poder Executivo, Brasília, DF, 27 abr. 1999. Disponível em: < http://www.planalto.gov.br/ccivil_03/leis/19795.htm>. Acesso em: 01 Out 2019.

Budzilo, V. C. (2016). Problemas ambientais do núcleo urbano de Reserva. Os desafios da escola pública paranaense na perspectiva do professor PDE, Produções DidáticoPedagógicas. Reserva-PR. Disponível em: $<$ http://www.diaadiaeducacao.pr.gov.br/portals/cadernospde/pdebusca/producoes_pde/20 16/2016_pdp_geo_uepg_valdecicarlosbudzilo.pdf>. Acesso em 01 Out 2019.

Carneiro, B. S.; Oliveira, M. A. S.; Moreira, R. F. (2016). Educação ambiental na escola pública. Revista brasileira de educação ambiental. São Paulo, v. 11, n.1, p. 25-36. Disponível em: <https://periodicos.unifesp.br/index.php/revbea/article/view/1893/1288>. Acesso em: 01 Out 2019.

Carvalho, I. C. de M. (2004). Educação ambiental: a Educação ambiental formação do sujeito ecológico. São Paulo: Cortez. Disponível em: $<$ https://books.google.com.br/books?hl=ptBR\&lr $=\& i d=$ o_VADwAAQBAJ\&oi $=$ fnd\&pg $=$ PT20\&dq $=$ educa $\% C 3 \% A 7 \% \mathrm{C} 3 \% \mathrm{~A} 3 \mathrm{o}+\mathrm{a}$

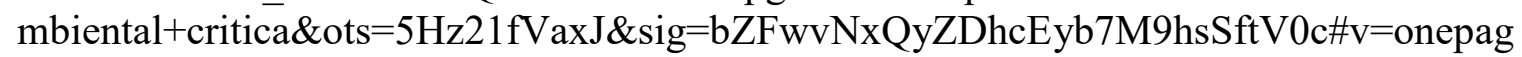
e\&q=brasil\%20\&f=false $>$. Acesso em: 30 Set. 2019.

Carvalho, V. F.; Silva, M. D. da; Silva, L. M. de S.; Borges, C. J.; Silva, L. A. da; Robazzi, M. 
L. do C. C. (2016). Riscos ocupacionais e acidentes de trabalho: percepções dos catadores de lixo. Revista de Enfermagem, UFPE online, Recife, v.10, n.4, p. 85-93. Disponível em: $<$ https://pdfs.semanticscholar.org/b951/eabbcaa5a2123fb3508ffc37853390613c10.pdfAce sso em: 30 Set 2019.

Cessa, R. M. A.; Souza, T. A. de; Silva, F. G. R.; Vitorino, A. C. T. (2013). Modelo digital de elevação do município de Confresa-MT. Revista Agrogeoambiental, Pouso Alegre, v. 5, n. 1, p. 75-84. Disponível em: $<$ https://agrogeoambiental.ifsuldeminas.edu.br/index.php/Agrogeoambiental/article/view/ 435>. Acesso em: 22 Jan 2020.

Cruz, C. A. da; Melo, I. B. N. de; Marques, S. C. M. (2016). A educação ambiental brasileira: história e adjetivações. Revista Brasileira de Educação Ambiental, São Paulo, v. 11, n.1, p. 183-195. Disponível em: <http://revbea.emnuvens.com.br/revbea/article/view/4718> Acesso em: 29 Set 2019.

Dias, G. F. (2014). Educação Ambiental - princípios e práticas. 9. ed. São Paulo, SP: Gaia.

Ferreira, J. C. V. (2017). História de Confresa. Portal Mato Grosso. Disponível em: $<$ http://www.portalmatogrosso.com.br/municipios/confresa/dados-gerais/historia-deconfresa/457>. Acesso em: 17 Nov 2019.

Figueiredo; C. A. M. dos S. (2017). Abordagem sobre educação ambiental na escola estadual Sol Nascente. 17 p. Conclusão do Curso de Especialização (Especialização em Educação no Campo) - Instituto Federal de Educação, Ciência e Tecnologia de Mato Grosso, Confresa.

Fonseca, S. M. (2016). A educação ambiental como disciplina. Revista Brasileira de Educação Ambiental, São Paulo, v. 11, n.1, p. 305-314. Disponível em: $<$ http://revbea.emnuvens.com.br/revbea/article/view/4154/3115>. Acesso em: 01 Out 2019.

Franco, A. R.; Morais, G. A. C. de; NETO, J. D.; Lopes, J. C. C.; Leucas, H. L. B. de; Guadalupe, D. de C.; Barros, M. D. M. de. (2012). Estudo de percepção ambiental com alunos de escola municipal localizada no entorno do Parque Estadual da Serra do Rola-Moça. Ambiente \& Educação, Rio Grande-RS, v. 1. n. 11, p. 155-175. Disponível em: < https://periodicos.furg.br/ambeduc/article/view/1845>. Acesso em: 14 Jan 2020.

GASPAR, J. V.; MENEGAZZO, C.; FIATES, J. E.; TEIXEIRA, C. S.; GOMES, L. S. R. (2017). A Revitalização de Espaços Urbanos: O Case do Centro Sapiens em Florianópolis. Revista Livre de Sustentabilidade e Empreendedorismo, v. 2, n. 4, p. 183-205, out-dez. Disponível em: <http://www.relise.eco.br/index.php/relise/article/view/104/102>. Acesso em: 29 Set 2019.

Gonçalves, A. A., Lima, M. E. O.; Marques, M. R. (2019). A percepção e educação ambiental com alunos do ensino fundamental. Belo Horizonte-MG: Centro Universitário de Belo Horizonte, Departamento de Ciências Biológicas. Disponível em: $<$ http://www.observatoriogeograficoamericalatina.org.mx/egal12/Ensenanzadelageogr afia/Metodologiaparalaensenanza/117.pdf>. Acesso em: 04 Out 2019.

Governo de Confresa. (2020). Recuperação das matas ciliares do córrego Cacau é o tema de uma reunião entre prefeitura de Confresa e parceiros. Disponível em: 
$<$ https://confresa.org/recuperacao-das-matas-ciliares-do-corrego-cacau-e-o-tema-de-umareuniao-entre-prefeitura-de-confresa-e-parceiros/>. Acesso em: 29 Jan. 2020.

Guimarães, M. (2016). Por uma educação ambiental crítica na sociedade atual. Revista Margens Interdisciplinar, Abaetetuba-PA, v. 7, n. 9, p. 11-22. Disponível em: $<$ https://periodicos.ufpa.br/index.php/revistamargens/article/view/2767>. Acesso em: 30 de Set de 2019.

Hofstatter, L. J. V.; Oliveira, H. T. de; souto, F. J. B. (2016). Uma contribuição da educação ambiental crítica para (des)construção do olhar sobre a seca no semiárido baiano. Ciência \& Educação, Bauru, v. 22, n. 3, p. 615-633, jul./set. Disponível em: $<$ http://www.scielo.br/scielo.php?script=sci_arttext\&pid=S151673132016000300615\&lang=eng>. Acesso em: 30 Set 2019.

IBGE. (2020). Confresa. Disponível em: $<$ https://cidades.ibge.gov.br/brasil/mt/confresa/panorama>. Acesso em: 22 Jan 2020.

Jardim, R. M. (2012). Revitalização de espaços urbanos ociosos como estratégia para a sustentabilidade ambiental: o caso do High Line Park no contexto do PlaNYC. 180 p. Dissertação (Mestrado em Engenharia Urbana e Ambiental) - Pontifícia Universidade Católica do Rio de Janeiro. Disponível em: <http://www.urb.pucrio.br/dissertacao/dissertacao_renata_jardim.pdf>. Acesso em: 29 Set 2019.

Junior, L. P. C.; Sá, L. P. (2017). Conhecimento pedagógico do conteúdo no contexto da educação ambiental: uma experiência com mestrandos em ensino de ciências. Revista Ensaio, Belo Horizonte, v.19, e2589. Disponível em: $<$ http://www.scielo.br/scielo.php?script=sci_arttext\&pid=S1983$21172017000100204 \&$ lang=en>. Acesso em: 30 Set 2019.

Leite, I. A.; Leite, C. A. (2017). Percepção de alunos acerca de educação ambiental em uma comunidade escolar, Patos-PB. Revista Biodiversidade, Rondonópolis-MT, v. 16, n. 2, p. 45-53. Disponível em: $<$ http://periodicoscientificos.ufmt.br/ojs/index.php/biodiversidade/article/view/5600>. Acesso em: 29 Nov 2019.

Lima, A. E. F.; Rocha, N. M. M. (2009). Dinâmica de parques urbanos em Fortaleza-CE: considerações sobre o parque Rio Branco. Conexões-Ciência e Tecnologia, v. 3, n. 1, p. 5361.

Disponível

em: $<$ http://www.conexoes.ifce.edu.br/index.php/conexoes/article/view/128>. Acesso em: 29 Set 2019.

Lima, G. A. de O.; Sobrinho, D. M. dos S. (2017). Educação ambiental nos anos iniciais do ensino fundamental. Disponível em: $<$ https://monografias.ufrn.br/jspui/bitstream/123456789/5771/3/Educa\%C3\%A7\%C3\%A 3o\%20ambiental_Artigo_2017.pdf $>$. Acesso em: 11 Jan 2020.

Marconi, M. de A.; Lakatos, E. M. (2007). Técnicas de Pesquisa. $6^{\text {th }}$ ed. São Paulo: Editora Atlas S. A.

Moura, D.; Guerra, I.; Seixas, J.; Freitas; M. J. (2006). A revitalização urbana cidades contributos para a definição de um conceito operativo. Comunidades e Territórios, n. 12/13,
p.
$15-34$.
Disponível
em:
$<$ https://repositorio.iscte- 
iul.pt/bitstream/10071/3428/1/Cidades2006-12-13_Moura_al.pdf $>$. Acesso em: 30 Set 2019.

Oliveira, D. E. R. (2018). Relatos de experiência e história da educação ambiental: grupo ecológico kaa-eté. In: 11 Encontro Internacional de Formação de Professores. Aracaju-SE, Anais. Disponível em: $<$ https://eventos.set.edu.br/index.php/enfope/article/view/9091>. Acesso em: 29 Set 2019.

Ostrovski, D.; Ostrovski, C. S. (2015). A percepção e educação ambiental de estudantes universitários. In: Educere, XII Congresso Nacional de Educação. Disponível em: $<$ https://educere.bruc.com.br/arquivo/pdf2015/16078_7385.pdf $>$. Acesso em: 24 Out. 2019.

Pádua, E. M. M. de. (2012). Metodologia da pesquisa: abordagem teórico-prática. 18 ed. Campinas, SP: Papirus. (Coleção Magistério: formação e trabalho pedagógico).

Pitanga, Â. F. (2016). Crise da modernidade, educação ambiental, educação para o desenvolvimento sustentável e educação em química verde: (re)pensando paradigmas. Ensino pesquisa educação e ciência, Belo Horizonte, v. 18, n. 3, 141-159. Disponível em: $<$ http://www.scielo.br/scielo.php?script $=$ sci_arttext\&pid=s1983-

$21172016000300141 \& \operatorname{lng}=\mathrm{en} \& n \mathrm{~nm}=\mathrm{iso}>$. Acesso em: 03 Out 2019.

Reis, D. A. dos; Silva, L. F. (2016). Análise de dissertações e teses brasileiras de Educação Ambiental: compreensões elaboradas sobre o tema "mudanças climáticas". Ciência \& Educação, Bauru, v. 22, n. 1, p. 145-162. Disponível em: $<$ http://www.scielo.br/scielo.php?script=sci_arttext\&pid=S1516-

$73132016000100145 \& \operatorname{lng}=\mathrm{en} \& n \mathrm{~nm}=$ iso $>$. Acesso em: 04 Out 2020.

Rodrigues, D. G.; Saheb, D. (2018). A educação ambiental na educação infantil segundo os saberes de Morin. Revista Brasileira de Estudos Pedagógicos, Brasília, v. 99, n. 253, p. 573-588, set./dez. Disponível em: $<$ http://www.scielo.br/scielo.php?script=sci_arttext\&pid=S217666812018000300573\&lng=en\&nrm=iso\&tlng=pt>. Acesso em: 30 Set 2019.

Rubira, F.G. (2016). Definição e diferenciação dos conceitos de áreas verdes/espaços livres e degradação ambiental/impacto ambiental. Caderno de Geografia, Minas Gerais, v. 26, n. 45, p. 134-150. Disponível em: $<$ http://periodicos.pucminas.br/index.php/geografia/article/view/P.23182962.2016v26n45p134>. Acesso em 30 Set 2019.

Silva, M. S. (2016). Crescimento urbano e degradação ambiental: a ausência de espaços livres no Residencial Novo Tempo em Timon-MA, 108p. Dissertação (Mestrado em Práticas em Desenvolvimento Sustentável) - Universidade Federal Rural, Rio de Janeiro. Disponível em: <https://tede.ufrrj.br/handle/jspui/2135>. Acesso em: 30 Set 2019.

Silva; N. C. da. (2017). Os desafios do ensino da educação ambiental em uma escola do campo: Um estudo de caso. $22 \mathrm{f}$. Trabalho de conclusão do Curso de Especialização (Especialização em Educação no Campo) - Instituto Federal de Educação, Ciência e Tecnologia de Mato Grosso, Confresa.

Sorrentino, M.; Trajber, R. (2007). Políticas de Educação Ambiental do Órgão Gestor. In: MELLO, Soraia Silva de (Coord.); TRAJBER, Rachel (Coord.). Vamos cuidar do Brasil: 
conceitos e práticas em educação ambiental na escola. Brasília: UNESCO, p. 13-21.

Stanganini, F. N.; Lollo, J. A. de. (2018). O crescimento da área urbana da cidade de São Carlos/SP entre os anos de 2010 e 2015: o avanço da degradação ambiental. Urbe, Revista Brasileira de Gestão Urbana, Curitiba, v. 10, supl. 1, p. 118-128, nov. 2018. Disponível em: $\quad<$ http://www.scielo.br/scielo.php?script=sci_arttext\&pid=S2175$33692018000400118 \& \operatorname{lng}=$ en\&nrm=iso $>$. Acesso em: 01 Nov 2019.

Sulaiman, S. N.; Aledo, A. (2016). Desastres naturais: convivência com o risco. Estudo Avançado, São Paulo, v. 30, n. 88, p. 11-23, dez. Disponível em: $<$ http://www.scielo.br/scielo.php?script=sci_arttext\&pid=S010340142016000300011\&lng=en\&nrm=iso>. Acesso em: 28 Jan 2020.

Tanscheit, P. (2017). Espaços Púbicos: a transformação urbana com a participação da população. Archdaily. Disponível em: <https//www.archdaily.com.br/br/875364/espaçospublicos-a-transformacao-urbana-com-a-participação-da-população $>$. Acesso em: 28 Jan 2020 .

Teixeira, L. C. (2016). Projeto de revitalização do parque aquático municipal da cidade de Arcos-MG. 99 f. Trabalho de Conclusão de Curso - Curso de Arquitetura e Urbanismo. Centro Universitário de Formiga, Formiga-MG.

Zancheti, S.; Somekh, N.; Fregonezi, B. (2015). Revitalização urbana no Brasil comparando seis centros históricos. Fórum Patrimônio: Ambiente Construído e Patrimônio Sustentável. Belo Horizonte, v.8, n.1. jan./jun. Disponível em: $<$ http://www.forumpatrimonio.com.br/seer/index.php/forum_patrimonio/article/view/151 >. Acesso em: 30 Set 2019.

Autores/as

Katiany dos Santos Pereira. https://orcid.org/0000-0002-3121-9692. Instituto Federal de Mato Grosso-Brasil. Graduação em Licenciatura em Biologia pelo Instituto Federal de Mato Grosso (IFMT). Técnica em Alimentos pelo IFMT Campus Confresa. Ativista da ONG ENGAJAMUNDO. Atua na Secretaria de Planejamento da Prefeitura de Confresa.

Marcelo Franco Leão. http://orcid.org/0000-0002-9184-916X.

http://lattes.cnpq.br/6237242675937692. Instituto Federal de Mato Grosso-Brasil. Doutorado em Educação em Ciências (UFRGS). Mestre em Ensino (UNIVATES). Especialização em Orientação Educacional (Dom Alberto) e em Relações Raciais na Educação e na Sociedade Brasileira (UFMT). Graduação em Licenciatura em Química (UNISC) e em Física (UNEMAT). Professor do Departamento de Ensino do IFMT Campus Confresa. Membro do Grupo de Pesquisa Ensino de Ciências e Matemática no Baixo Araguaia (EnCiMa). 